\title{
The conditions of self-awareness among faculty member on excellent academic services
}

\author{
Taufik Taufik ${ }^{1}$, Ifdil Ifdil ${ }^{2}$ \\ ${ }^{12}$ Universitas Negeri Padang
}

\begin{abstract}
Supposed educators can provide excellent service to consumers, in the academic community of Universitas Negeri Padang. Universitas Negeri Padang comes in at the 61st (sixty-one) out of the 100 (one hundred) best universities in Indonesia. Being one of the best universities in Indonesia's educators should have excellent service to consumers who in this case are students. However, in fact, many educators still do not have selfawareness (self-awareness) awareness) in providing excellent service to consumers. This is evidenced by the identification of self-awareness conditions of respondents in the high category is still low compared to the medium category. The following report will describe the condition of self-awareness of educators.
\end{abstract}

Keywords: self-awareness, educators, excellent services

\section{INTRODUCTION}

Every human activity does not escape from service or service among human beings. This is because humans need each other from one another (Batinggi, A., \& Ahmad, B. 2014; Hulam, T. 2010; Surachim, A. 2008). Service is divided into two types: physical service personal as human being and administration service given to others as a member of organization (Suryono, A. 2001; Batinggi, A., \& Ahmad, B. 2014). Services or services used by humans such as a health care (Aeni, IN 2011), transportation services (Pakambanan, WB 2016), administrative services (Nim, APAK 2015), service in academic community (Rinala, IN, Yudana, IM)

Natajaya, IN 2013) and so forth. Service is an activity undertaken by a person or group of people assuming a material factor through certain systems, procedures and methods to fulfill the interests of others under their rights (Moenir, 2010). Service can also be said as an activity or sequence of activities that occur in direct interaction between someone with another person or machine, and provide customer satisfaction (Sampala in Sinambela 2011; Neely, A., Gregory, M., \& Platts, K. 1995).

The services given should be able to reach the excellent service (Hennig-Thurau, T. 2004; Matin, I, Hulme, D., \& Rutherford, S. 2002) Which provides individual satisfaction (Khoirunnisa, AF, Setyanto, NW, Oktavianty, O. 2014). So also with the services provided by an educator's academic community in Higher

Education. Considering the increasing competition, the service of higher education needs to improve under satisfactory elements of service (Brysland, A., \& Curry, A. 2001; Herrmann, A., Huber, F., \& Braunstein, C. 2000; Rosen, DE, \& Surprenant, C. 1998). This is due to individuals who choose in Higher Education cannot be separated from the elements of service and student satisfaction for education services got. Service is the core of the business in service. Service very depends on the services provided to consumers who in this case are students.According to Gilbert Lumpkin and Dant (1992) the successful fulfillment of satisfaction has gained the dominant and strategic attention in service. The academic service provided by the university is one measure of the success of highereducation institutions in managing their educational institutions in providing education services (Mulyawan, A., \& 
Sidharta, I. 2014; Angreany, S. 2013). This resulted in educational institutions need to improve service and academic quality (Mulyawan, A., \& Sidharta, I. 2013).

\section{METHOD}

This research is planned to identify the condition of self-awareness of an educator. The research population is educators at Universitas Negeri Padang. The sample of this study amounted to 287 respondents drawn by a sampling technique is Proportionate Stratified Random Sampling. Data analysis technique used in this research is descriptive (Yusuf, A. M. 2005) with technique percentage (Sudjana, 2001) to describe self-awareness.

\section{RESULTS AND DISCUSSIONS}

\begin{tabular}{|c|c|c|c|c|c|}
\hline \multicolumn{6}{|c|}{ Table 1. Overall Awareness Level } \\
\hline & & Frequency & Percent & Valid Percent & Cumulative Percent \\
\hline \multirow[t]{3}{*}{ Valid } & Medium & 119 & 71.3 & 71.3 & 71.3 \\
\hline & High & 48 & 28.7 & 28.7 & 100.0 \\
\hline & & 167 & 100.0 & 100.0 & \\
\hline
\end{tabular}

Table 1 shows that the highest level of self-awareness among respondents is in the moderate category of $71.3 \%$. The remaining $28.7 \%$ of respondents' self-awareness is in the high category. Based on this case it can be concluded that self-awareness of respondents in the high category is still low compared to the medium category. Here the level of self-awareness in the medium category that needs to be improved to reach the state of consciousness at a high stage. As explained by (Muzakar, 2012) self-awareness is a skill associated with the employee's need to better cope with change and force it to identify how they can succeed in a particular situation. Self-awareness (self-awareness) awareness) helps to improve the quality of service. The sign that officers who have self-awareness improve the quality of service through customer satisfaction. Improving the quality of service can be done if the high selfawareness of officers in the service provided. It is thus supported by (Rahmasari, 2016) self-awareness is the ability to know what is felt within itself and use it to guide self-making decisions. Therefore, if the high self-awareness of the officer can take a wise decision in providing every service to various customers.

Every individual must understand the importance of self-awareness. Self-awareness is a state in which a person can understand himself exactly. A person is called self-awareness if one understands the emotions and mood that are being felt, the crisis of information about himself, and conscious of his real self (Achmanto Mendatu, 2010).

Brigham (1992), put forward self-awareness is a state in man when directing his inward attention to focus on the contents of the self or the degree of attention directed inward to focus on the self. Self-awareness consists of two types, among others: 1) Awareness self-personal (self-awareness) is focused on the self-relative aspects such as mood, perception, and feelings. People who have this kind of dominant awareness will more quickly process information that refers to itself and have a more consistent self-image. 2) Public awareness (public self-awareness) that is attention is directed to aspects of dirt that appear or visible to others such as appearance and social action. People who have a high public self-awareness will tend to pay attention to their social identity and other people's reactions to them.

Based on that opinion it can be concluded that self-awareness is an important trait that must exist in the individual to be able to recognize, recognize or feelings of others and self or also situations where a person can understand himself, self-awareness is also a requirement to work effective and efficient.

The self-awareness factor menu according to Schuler (1990) factors in an integrated planning in accordance to to the needs for progress within an organization to change caserean themselves, among others: 1) willing to adapt quickly to predict unexpected changes, 2) increased cost, because competition for predicting unexpected changes, 3) rapid technological change leading to increased demand, 4) beter skill-drivenemployees through education and training, 5) more complex organizations relate to products, geography, business and comsumer functions (markets), 6) response to external forces related to legislation and relativity, judicial processes, and other regulations, 7) structural changes in a more flexible, later and more (leaner) organizational performance will lead in the number of 
employees and the type of work faced differently, 8) increased competition and international cooperation nail, 9) there is a diversity of performance forces.

Self-awareness in this study is modified rather than the theory of the Personal Indentity Model by Arredondo \& Glauner (in Baruth \& Manning, 2007) which focuses upon the concept of self-awareness that embraces trust, knowledge and skill. According to (Baruth \& Manning, 2007) there are three specs, including self-awareness that is: 1) Trust. Beliefs include aspects of demography, education. Individual work experiences factors. The counselor must develop self-awareness to practice his attitudes and beliefs. According to Baruth \& Manning's beliefs (beliefs) will foster a sense of individual self-awareness (Baruth \& Manning, 2007). Belief (belief) becomes the most important thing in improving self-awareness to the individual especially related to the service. 2) Knowledge. Individuals must have special knowledge related to controlling of the collection as well as to the client (individual) (Baruth \& Manning, 2007). The knowledge aspect includes individual knowledge, especially in service. 3) Proficiency. Selfawareness is needed to assist the counselor in order for individual skills in service delivery to be memorable (Baruth \& Manning, 2007). Skill (dealing) deals with individual professionalism, especially in service.

\section{CONCLUSIONS}

Based on the results of research that has been done then it can be concluded that the level of self-awareness of respondents as a whole is in the category of being. So that self-awareness respondent in some categories such as age, gender, educational background, length of work, employment status, and ethnic need to be improved in order to achieve excellent service.

\section{REFERENCES}

Aeni, I. N. (2011). Program pelayanan kesehatan yayasan persada nurani dalam masyarakat kesehatan miskin di Kebayuran Lama Jakarta Selatan.

Angreany, S. (2013). Pengaruh Kualitas Layanan Pendidikan Terhadap Indeks Prestasi Kumulatif Mahasiswa di Program Studi S1 Akuntansi Universitas X Makassar.

Baruth, L. G., \& Manning, M. L. (2007). Multicultural Counseling and Psychotherapy: A Lifespan Perspective: Merrill.

Batinggi, A., \& Ahmad, B. (2014). Manajemen Pelayanan Umum.

Brigham, Eugene F., 1992, Fundamental Of Finance Management, $6^{\text {th }}$ Edition, The Dryden Press Harcourt Brace Collage Publisher, Orlando USA.

Brysland, A., \& Curry, A. (2001). Service improvements in public services using Servqual. Managing Service Quality: An International Journal, 11(6), 389-401.

Gilbert, F. W., Lumpkin, J.R., dan Dant, R. P. (1992). "Adaptation and Customer Expectation of Health Care Options."Journal of Health Care Marketing, 12(3) a:46-55.

Hennig-Thurau, T., \& Klee, A. (1997). The impact of customer satisfaction and relationship quality on customer retention: A critical reassessment and model development. Psychology \& marketing, 14(8), 737-764.

Herrmann, A., Huber, F., \& Braunstein, C. (2000). Market-driven product and service design: Bridging the gap between customer needs, quality management, and customer satisfaction. International Journal of production economics, 66(1), 77-96.

Hulam, T. (2010). Jaminan Dalam Transaksi Akad Mudharabah Pada Perbankan Syariah. Mimbar Hukum-Fakultas Hukum Universitas Gadjah Mada, 22(3), 520-533.

Matin, I., Hulme, D., \& Rutherford, S. (2002). Finance for the poor: from microcredit to microfinancial services. Journal of International Development, 14(2), 273-294.

Moenir. (2010). Manajemen Pelayanan Umum Di Indonesia. Jakarta: Bumi Aksara.

Mulyawan, A., \& Sidharta, I. (2013). Analisis Deskriptif Pemasaran Jasa Di STMIK Mardira Indonesia Bandung. Jurnal Computech \& Bisnis, 7(1), 42-55.

Mulyawan, A., \& Sidharta, I. (2014). Determinan Kualitas Layanan Akademik Di STMIK Mardira Indonesia Bandung. Jurnal Computech \& Bisnis, 8(1), 13-24.

Muzakar, I. (2012). Analisis Kompetensi Kewirausahaan, Orientasi Kewirausahaan, dan Kinerja Industri Mebel. Benefit: Jurnal Manajemen Dan Bisnis, 15(2), 135-149.

Neely, A., Gregory, M., \& Platts, K. (1995). Performance measurement system design: a literature review and research agenda. International journal of operations \& production management, 15(4), 80-116. 
Nim, A. P. A. K. (2015). Kualitas Pelayanan Administrasi Pembuatan Kartu Tanda Penduduk Elektronik (E-KTP) di Kecamatan Nanga Tayap Kabupaten Ketapang. Governance, 4(3).

Pakambanan, W. B. (2016). Tinjauan Hukum Pelaksanaan Pengangkutan Barang Melalui Layanan Go-Send GoJek Indonesia (Doctoral dissertation).

Rahmasari, L. (2016). Pengaruh Kecerdasan Intelektual, Kecerdasan Emosi dan Kecerdasan Spiritual Terhadap Kinerja Karyawan. Majalah Ilmiah Informatika, 3(1).

Rinala, I. N., Yudana, I. M., \& Natajaya, I. N. (2013). Pengaruh Kualitas Pelayanan Akademik Terhadap Kepuasan dan Loyalitas Mahasiswa Pada Sekolah Tinggi Pariwisata Nusa Dua Bali. Jurnal Administrasi Pendidikan, 4(1).

Rosen, D. E., \& Surprenant, C. (1998). Evaluating relationships: are satisfaction and quality enough?. International journal of service industry management, 9(2), 103-125.

Samosir, Z. Z. (2009). Pengaruh kualitas pelayanan terhadap kepuasan mahasiswa menggunakan perpustakaan USU.

Schuler P. (1990). Natural Antioxidant Exploited Comercially. Di dalam: "Food Antioxidants". Husdont BJF, editor. New York: Elsevier Applied Science.

Sudjana, D. (2001). Metode dan Teknik Pembelajaran Partisipatif. Falah Production.

Surachim, A. (2008). Pengaruh Iklim Organisasi terhadap Kepuasan Kerja Karyawan Pada Divisi Pharmaserve Di PT Combiphar Jakarta. strategic, 7(13), 58-64.

Suryono, A. (2001). Budaya Birokrasi Pelayanan Publik. Jurnal Administrasi Negara, 1(2), 49-58.

Yusuf, A. M. (2005). Metode penelitian. Universitas Negeri Padang, Padang. 